\title{
An overview of barley breeding and variety trials in Iceland in 1987-2014
}

\author{
Hrannar Smári Hilmarsson ${ }^{1}$, Magnus Göransson ${ }^{1,2}$, Morten Lillemo², Pórdís Anna \\ KRISTJÁNSDÓTTIR ${ }^{1}$, Jónatan HERmanNSSON ${ }^{1}$ and Jón HaLLSTEINN HaLLSSON ${ }^{1}$

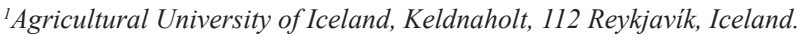 \\ ${ }^{2}$ Department of Plant Sciences, Norwegian University of Life Sciences, P.O. Box 5003, NO-1432 As, Norway. \\ E-mail: jonhal@lbhi.is (correspondingauthor)
}

\begin{abstract}
Barley is of great importance in modern agriculture and is currently the fourth most important cereal after wheat, maize, and rice. It is well adapted to a range of climatic and day-length conditions, with a distribution from Ethiopia to northern Scandinavia. Despite this, Iceland, with its sub-arctic agriculture, is considered to be at the margin of barley cultivation. Still the importance of barley has steadily increased in Icelandic agriculture, most likely as the result of positive environmental change, continuous testing of new Nordic cultivars, and an Icelandic barley breeding project. Here we present a review of the results from barley cultivar trials from 40 locations over a 28-year period in Iceland in the years 1987-2014. The results showed that yields were rising and the time from sowing to harvest was getting shorter. Also, the Icelandic genotypes were heading earlier, while showing higher yields. The results also showed that test locations were getting fewer but at the same time the number of tested genotypes was increasing. The analysis presented here highlights both the strengths and weaknesses of the current breeding program and is therefore an important basis for future breeding projects for Icelandic agriculture and possibly for other small scale breeding projects aimed at peripheral areas.
\end{abstract}

\section{YFIRLIT}

Yfirlit um byggkynbcetur og yrkjatilraunir á Íslandi 1987-2014.

Bygg er mikilvæg nytjaplanta og er í fjórða sæti yfir mikilvægustu korntegundir í heiminu á eftir hveiti, maís og hrísgrjónum. Pó bygg hafi aðlagast fjölbreytilegum umhverfisskilyrðum, bæði loftslagi og daglengd, pá er ræktun á jaðri heimskautasvæðanna enn á mörkum pess mögulega, sem endurspeglast meðal annars í stuttri ræktunarsögu byggs á Íslandi og peim erfiðleikum sem steðja að byggræktendum hérlendis. Prátt fyrir pað pá hefur mikilvægi byggs fyrir íslenskan landbúnað aukist nokkuð stöðugt undanfarin ár, sem meðal annars hefur verið skýrt sem afleiðing batnandi umhverfisskilyrða, prófana á erlendum byggyrkjum og kynbóta sérstaklega fyrir íslenskar aðstæður. Hér birtum við niðurstöður úr samanburðartilraunum á byggi sem fram hafa farið á 40 stöðum yfir 28 ára tímabili á árunum 1987-2014. Gögnin sýndu að tilraunastöðum fækkaði á meðan arfgerðum í tilraunum fjölgaði. Niðurstöðurnar sýndu að uppskera í tilraunum jókst á sama tíma og ræktunartímabilið styttist. Íslensku kynbótalínurnar skiluðu ekki aðeins meiri uppskeru í tilraunum heldur skriðu pær einnig fyrr. Niðurstöðurnar sem kynntar eru hér undirstrika bæði kosti og galla kynbótaverkefnisins og eru pví mikilvægar áframhaldandi byggyrkjatilraunum fyrir íslenskan landbúnað og geta ef til vill nýst öðrum sambærilegum verkefnum á jaðarsvæðum.

Key words: Barley, breeding, cultivar testing, marginal environment, sub-arctic agriculture. 


\section{INTRODUCTION}

Barley (Hordeum vulgare L. ssp. vulgare) is assumed to have been domesticated from multiple wild progenitor populations most likely with a distribution similar to the current distribution of the wild relative $H$. vulgare $\mathrm{L}$. ssp. spontaneum (Poets et al. 2015). Since its early domestication barley has been adapted to a great range of both climatic and day-length conditions, possibly assisted by the genetic diversity incorporated through a multicentric domestication process (Allaby 2015). Barley is of great importance in modern agriculture and is the fourth most important cereal in the world after wheat, maize and rice (FAO 2017).

Well suited to harsh climates, barley is by far the most important cereal crop in Iceland, where it is currently cultivated on around 5000 hectares with a top annual harvest of up to 16000 tons seen, for example, in the years 2009 and 2012 (Figure 1A). Despite this, the sub-arctic agriculture, characterized by a short and cool growth period, occasional very strong winds, risk of frost in both late spring and early autumn, and a long photoperiod, is still at the margin of barley cultivation. This is emphasized by the short continuous history of barley cultivation in Iceland, where it has been cultivated continuously only since 1923 (Hermannsson 1993), as well as the fluctuations in total harvest from year to year during that period.

It is generally assumed that the early Icelandic settlers brought barley with them to Iceland in the $9^{\text {th }}$ century and that Icelanders cultivated barley until sometime during the $13^{\text {th }}$ century (Karlsson 2009). The reason for the abandonment of barley cultivation in Iceland is not known but two non-mutually exclusive ideas have been proposed. Firstly, climate change has been suggested to have negatively affected the growing conditions during the socalled Little Ice Age that is believed to have started between 1275 and 1300 (Miller et al. 2012). Secondly, lowering prices of barley in Europe and increased trade between Iceland and Europe, possibly coupled to worsening growing conditions, may have reduced the benefits of growing barley in Iceland (Karlsson 2009).

After the resumption of barley cultivation in Iceland, barley field trials have been conducted on and off since the middle of the $20^{\text {th }}$ century. In 1960, the Swedish cultivar 'Mari' was released (Gustafsson et al. 1971, Lundqvist 2008), produced by induced mutagenesis from the cultivar 'Bonus'. 'Mari' carries a deletion in the circadian clock regulator Mat-a gene, making it day length neutral, which results in
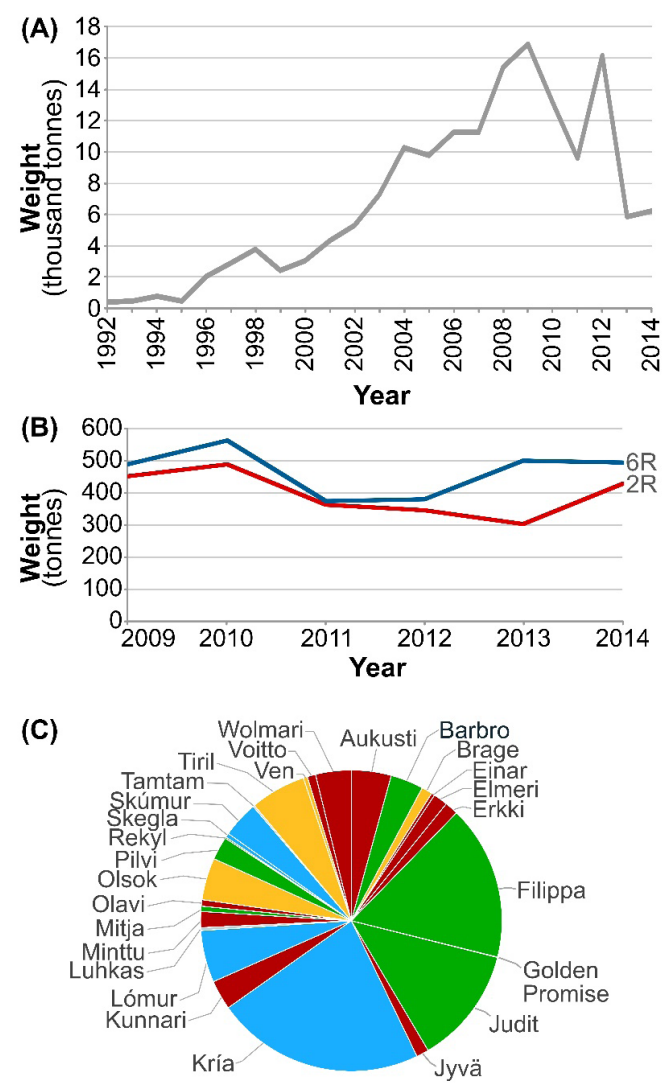

Sweden (36\%) Iceland (32\%)

Finland $(19 \%) \quad$ Norway $(12 \%) \quad$ Other $(1 \%)$

Figure 1. An overview of barley cultivation in Iceland. (A) Total barley harvest in Iceland in 1992 to 2014. (B) Amount of barley seed imported in 20092014, distinguishing between two-rowed (2R) and six-rowed (6R) cultivars. (C) Barley cultivars imported in 2009-2014, color coded based on the country of origin, with percentage of total imports from different countries in parentheses. 
an early flowering phenotype (Gustafsson et al. 1971, Zakhrabekova et al. 2012). In addition, 'Mari' has a strong straw, making it resistant to lodging (Gustafsson et al. 1971, Zakhrabekova et al. 2012). The cultivar was grown in Iceland up until the 1980s with little success but has been used in crosses in the Icelandic breeding program.

As a result of a small-scale Icelandic barley breeding project, four cultivars have been made commercially available by the Agricultural University of Iceland (previously the Agricultural Research Institute). These are 'Skegla' released in 2002, 'Kria' released in 2004 (CPVO 2016), 'Lomur' released in 2007, and 'Skumur' released in 2008.

Barley seeds used by Icelandic farmers are imported and seed import is filed at the Icelandic Food and Veterinary Authority (www.mast.is). Each year about 1000 tons of barley seeds are imported; for example in 2014 a total of 924 tons of barley seeds were imported, with close to equal amounts of 2-rowed and 6-rowed cultivars (Figure 1B). The barley cultivars selected for import are mostly Norwegian, Finnish, and Swedish, in addition to the Icelandic lines that account for $32 \%$ of the Icelandic seed market, with 'Kria' being the most popular. Imported cultivars with large market shares include 'Filippa', 'Aukusti', 'Judit', and 'Wolmari' (Figure 1C). The lack of detailed data on grain yield in farmers' fields makes assessment of cultivar selection problematic, but data from field trials could give an overview of yield potential in Iceland and aid farmers in selecting the best suited cultivars for Icelandic environmental conditions.

Improvement due to barley breeding projects has been studied in several countries. In Norway, for example, a 70\% yield increase in farmers' fields was observed in the period 1946-2008 (Lillemo et al. 2010). About a 40\% increase in yield due to new cultivars was observed from 1880-1980 in England and Wales (Riggst et al. 1981). Ortiz et al. (2002) found a $13 \%$ and $34 \%$ genetic gain in Nordic spring barley for 2-row and 6-row cultivars, respectively, in a sixty-year period. In contrast, results from barley breeding in Finland from 1920-1987 showed no genetic improvement in yield (Peltonen-Sainio \& Karjalainen 1991).

Although the results of field trials in Iceland are reported each year, a comprehensive review of the results has been lacking as well as an overall estimate of genetic improvement, especially for the Icelandic barley cultivars. Here we review data from 28 years of barley variety testing in the period 1987-2014, including results for the Icelandic breeding material. The primary aim of the analysis presented here was to describe the plant breeding and cultivar trials in Iceland and the difference between the Icelandic breeding material and foreign genotypes that were tested under the same conditions in Iceland during this period. This analysis is an important step in the ongoing Icelandic barley breeding project and will provide Icelandic farmers with valuable information on available cultivars.

\section{MATERIALS AND METHODS \\ Collected data}

Data from annual cultivar trials for the period 1987-2014, a total of 28 years and 40 locations, were selected for analysis. Although barley trials have been conducted in Iceland for a longer period, and in a total of 60 locations, the dataset under review here was available in digital format and the trials all conducted in a similar fashion. Results for the cultivar trials have been published earlier in annual field trial reports (Fjölrit RALA 1988-2014, Rit LbhÍ 2005-2015) but the analysis presented here is based on a complete reanalysis of the original field data.

The trials were generally set up in an alphalattice design with two or three replicates, although in some cases other experimental setups were used, but as this study is an overview of the total variation within and between trials during the timespan we chose to base analyses on raw data from each plot. Samples where plot data from replicates were missing were deleted from the dataset. Though sometimes sown and harvested by hand, machinery has been the standard way of sowing and harvesting in all locations since the year 1999 - using a 
Wintersteiger sowing machine model 1982 and a Wintersteiger A-4910 thresher model 1998. In the 28 -year period a total of 14133 plots were harvested. For all genotypes included in each experiment for every given location, the sowing and harvest dates were the same. The amount of fertilizer was equal for all plots in each location and no fungicides or pesticides were applied. The data collected from the barley trials included the following variables, although not all variables are available for all years or locations: Day of sowing, day of heading, day of harvest, estimated yield in hkg DM ha-1, thousand-kernel weight (TKW) in $\mathrm{g}$, weight by volume $(\mathrm{w} / \mathrm{v})$ in $\mathrm{g} \mathrm{dL}^{-1}$, height of straw $(\mathrm{H})$, and dry matter (DM) standardized as $100 \%$ dry. In addition to the above measurements, several others were recorded, in some cases at multiple locations but often only at the Korpa experimental station; of the 14133 plots included in the field trials fungal infection was assessed for 2024 plots, soil type, use of nitrogen fertilizers and $\mathrm{pH}$ levels were recorded for 13419, 13419 and 2188 plots, respectively. Straw breakage was assessed for 567 plots, seed fall for 315 plots, straw height for 4972 plots, and lodging was assessed for 1801 plots. Although these measurements are a part of the dataset, the analysis of these measurements was considered outside the scope of the work presented here and will be addressed elsewhere.

\section{Test locations and cultivars tested}

The tests analysed here were carried out at the following 40 locations, with three letter codes and coordinates shown in Table 1 and the distribution of test locations in Iceland shown in Figure 2: with three locations in the northwestern part of Iceland (Westfjords), eleven locations in both northern and southern Iceland, seven locations in eastern Iceland, and eight locations in western Iceland (Figure 2).

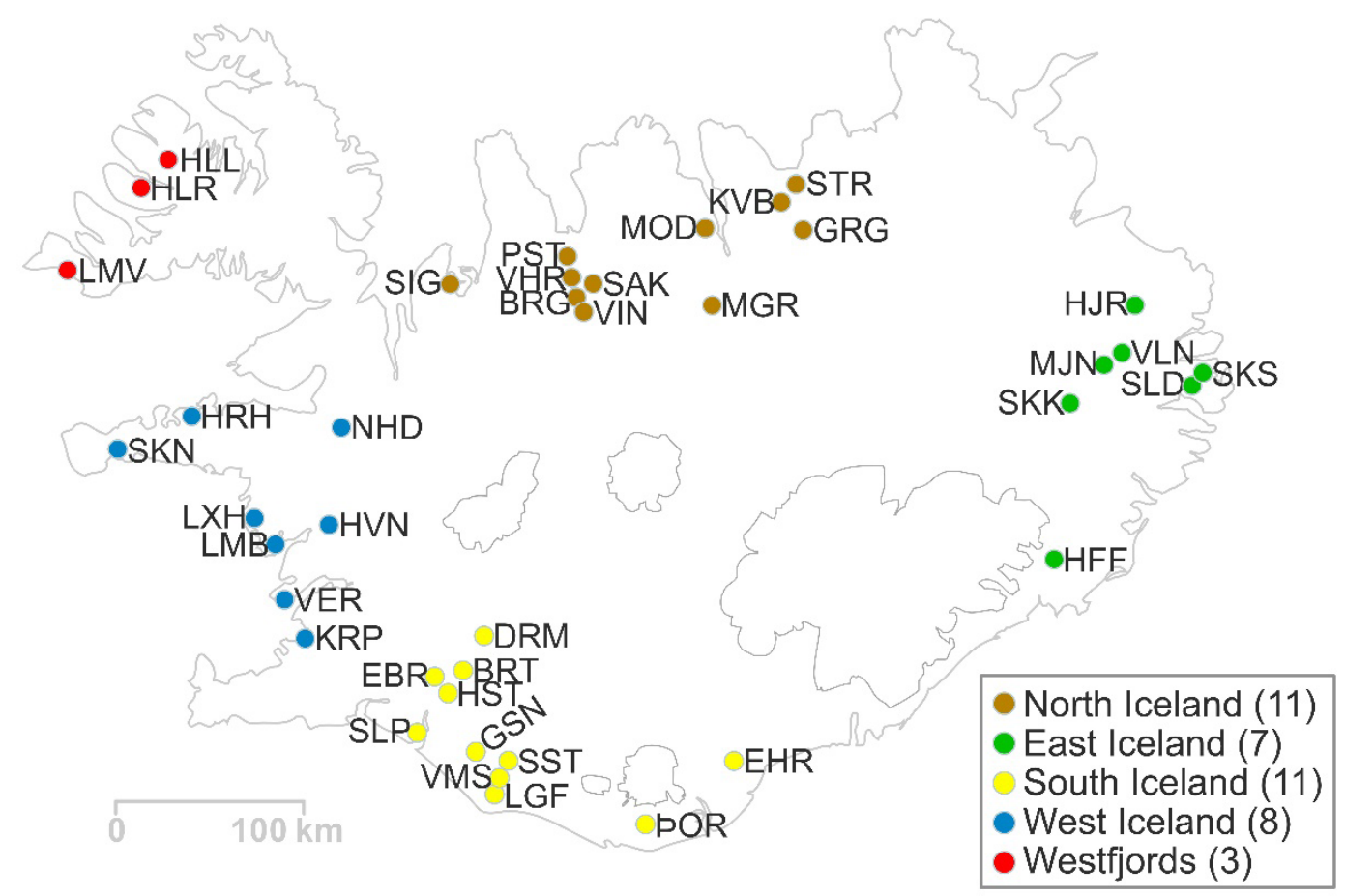

Figure 2. A geographical overview of test locations used in 1987-2014. A total of 40 locations were included in the analysis, with test locations color coded based on geographical location and the total number of test locations shown in parentheses. 
Table 1. Names of test locations, three letter codes and corresponding GPS coordinates.

\begin{tabular}{llllllll}
\hline Farm & In. & \multicolumn{2}{c}{ Coordinates } & Farm & In. & \multicolumn{2}{c}{ Coordinates } \\
\hline Birtingaholt & BRT & 64.068206 & -20.426564 & Miðgerði & MGR & 65.494875 & -18.190292 \\
Borgarey & BRG & 65.514108 & -19.389947 & Mjóanes & MJN & 65.150131 & -14.636009 \\
Drumboddstaðir & DRM & 64.225098 & -20.294706 & Möðruvellir & MOD & 65.770216 & -18.249191 \\
Efri-Brúnavellir & EBR & 64.037048 & -20.522500 & Neðri-Hundadalur & NHD & 64.976403 & -21.608741 \\
Eystra-Hraun & EHR & 63.717955 & -17.993623 & Páfastaðir & PST & 65.635460 & -19.526431 \\
Geitasandur & GSN & 63.790504 & -20.293323 & Sámsstaðir & SST & 63.734602 & -20.107432 \\
Grundargil & GRG & 65.754595 & -17.399764 & Selárdalur & SLD & 65.104364 & -13.869573 \\
Hjartarstaðir & HJR & 65.410034 & -14.312513 & Selpartur & SLP & 63.810278 & -20.737350 \\
Hoffell & HFF & 64.391560 & -15.332523 & Sigríðarstaðir & SIG & 65.561602 & -20.599496 \\
Hóll & HLL & 65.969796 & -23.332611 & Skorrastaður & SKS & 65.126116 & -13.795362 \\
Hólar & HLR & 65.867901 & -23.565749 & Skriðuklaustur & SKK & 65.041443 & -14.950879 \\
Hraunháls & HRH & 64.987144 & -22.901652 & Stóru-Akrar & SAK & 65.538339 & -19.312699 \\
Húsatóftir & HST & 64.026201 & -20.485249 & Straumnes & STR & 65.879112 & -17.415253 \\
Hvanneyri & HVN & 64.564055 & -21.765312 & Syðri-Knarrartunga & SKN & 64.833033 & -23.494384 \\
Korpa & KRP & 64.151212 & -21.752695 & Vallanes & VLN & 65.194779 & -14.537400 \\
Kvíaból & KVB & 65.822057 & -17.558689 & Vallhólmur & VHR & 65.566839 & -19.430081 \\
Lambastaðir & LMB & 64.475702 & -22.088488 & Vestri-Reynir & VER & 64.315488 & -21.985752 \\
Lambavatn & LMV & 65.493258 & -24.092692 & Vindheimar & VIN & 65.504136 & -19.369007 \\
Laxárholt & LXH & 64.597725 & -22.316615 & Voðmúlastaðir & VMS & 63.655422 & -20.175582 \\
Lágafell & LGF & 63.596642 & -20.187330 & borvaldseyri & DOR & 63.545654 & -19.660428 \\
\hline & & & & & & &
\end{tabular}

Data on barley cultivars imported to Iceland are available from the Icelandic Food and Veterinary Authority (www.mast.is). It is not known which cultivars farmers use and whether farmers use them differently in different parts of the country.

Calculations were performed in Microsoft Excel (2010) with the XLSTAT addition (2015), with the exception that the LSmeans package available in R-studio (version 1.0.136) was used to fit a linear model to calculate the least square means (lsmeans) for yield (hkg DM ha-1) of each year. Lines that were tested in at least two different years and in two different places were included in the analysis. A total of 314 genotypes were used to calculate the lsmeans (from 10061 plots) for each year across farms $(n=31)$. The lsmeans were then compared to the mean annual temperature of Stykkishólmur (the reference weather station for Iceland) for the average growing season (4 May - 17 September).

\section{RESULTS}

Test locations and number of cultivars tested The number of test locations were similar between the four main regions of Iceland, with many fewer locations in the Westfjords (Figure 2 ). The total number of test locations per year varied from 12 in 1992 to three and four locations in 2013 and 2014, respectively, with clear emphasis on larger tests in fewer places (Figure 3). The last test in the Westfjords was 1999 and in eastern Iceland in 2005; since then tests have been carried out at six locations, one in the south (POR), two in western Iceland 


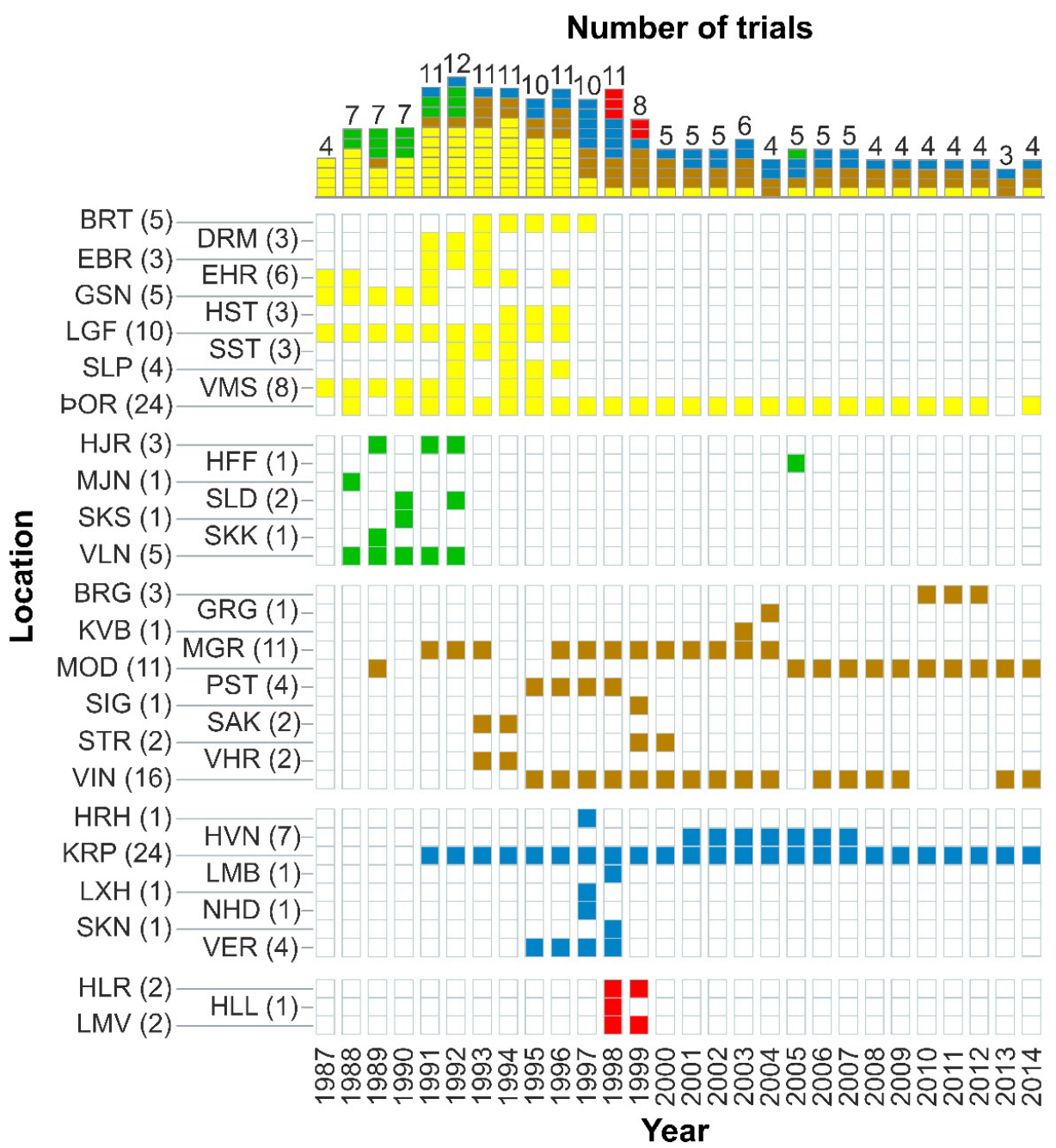

Figure 3. An overview of test locations in 1987-2014. Time dependent changes in the total number of test locations used and an overview of when different locations were used for cultivar trials. Color coded as in Figure 2.

(KRP and HVN), and three locations in northern Iceland (VIN, MOD, and BRG). During the 28 years, 13 test locations have been used once and 12 locations 2 or 3 times (Figure 3). The most frequently used test locations were VIN in the northern part of Iceland with 16 tests since the year 1995, KRP in the west with 24 tests since the year 1991, and POR in the south with 24 tests since 1988 (Figure 3). No single test location was used consecutively throughout the period under review (Figure 3). Around 65\% of the plots were grown in four locations: 5031 plots at KRP, 1572 plots at $\mathrm{POR}, 1318$ plots at MOD, and 1254 plots at VIN (Figure 4) which resulted in an uneven distribution of tests.

In a 28-year period a total of 14133 plots were harvested, giving an average number of 514 plots per year, ranging from 303 plots in the year 1989 to 804 plots in the year 2010 (Figure 5A). A total of 901 different genotypes were tested in these trials, including 88 established cultivars. An average number of 33 lines or cultivars that 


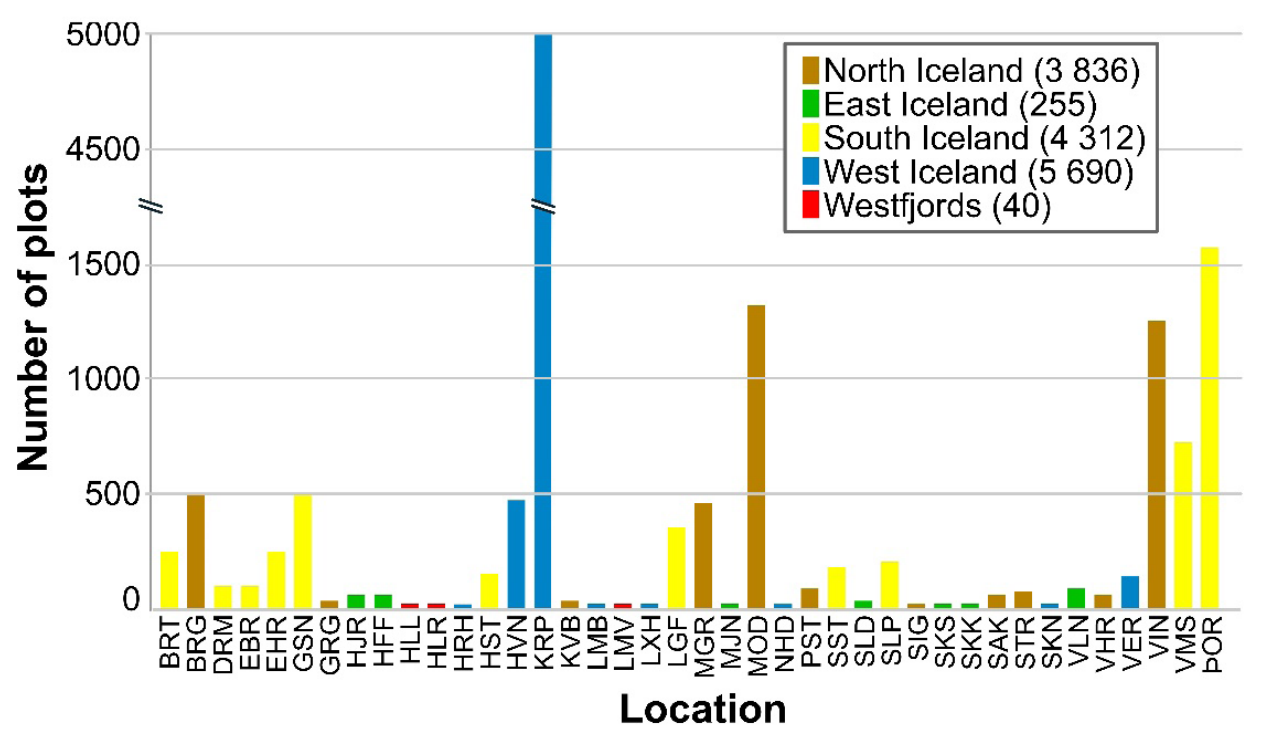

Figure 4. Number of plots harvested and distribution of cultivar tests between parts of Iceland in 1987-2014. Total number of tests at the forty different test locations. Due to the large number of tests carried out at Korpa (KRP) the Y-axis is broken for clarity. The total number of plots in different parts of Iceland is shown in parentheses in the legend.

had not been tested before were tested each year since 1988, ranging from 4 in 1991 to 135 in the year 2010 (Figure 5B). A large proportion of the lines tested were tested only a few times, with a distribution from 1 test for 252 lines to 129 and 126 tests for two of the lines tested during the period under review (Figure 5C).
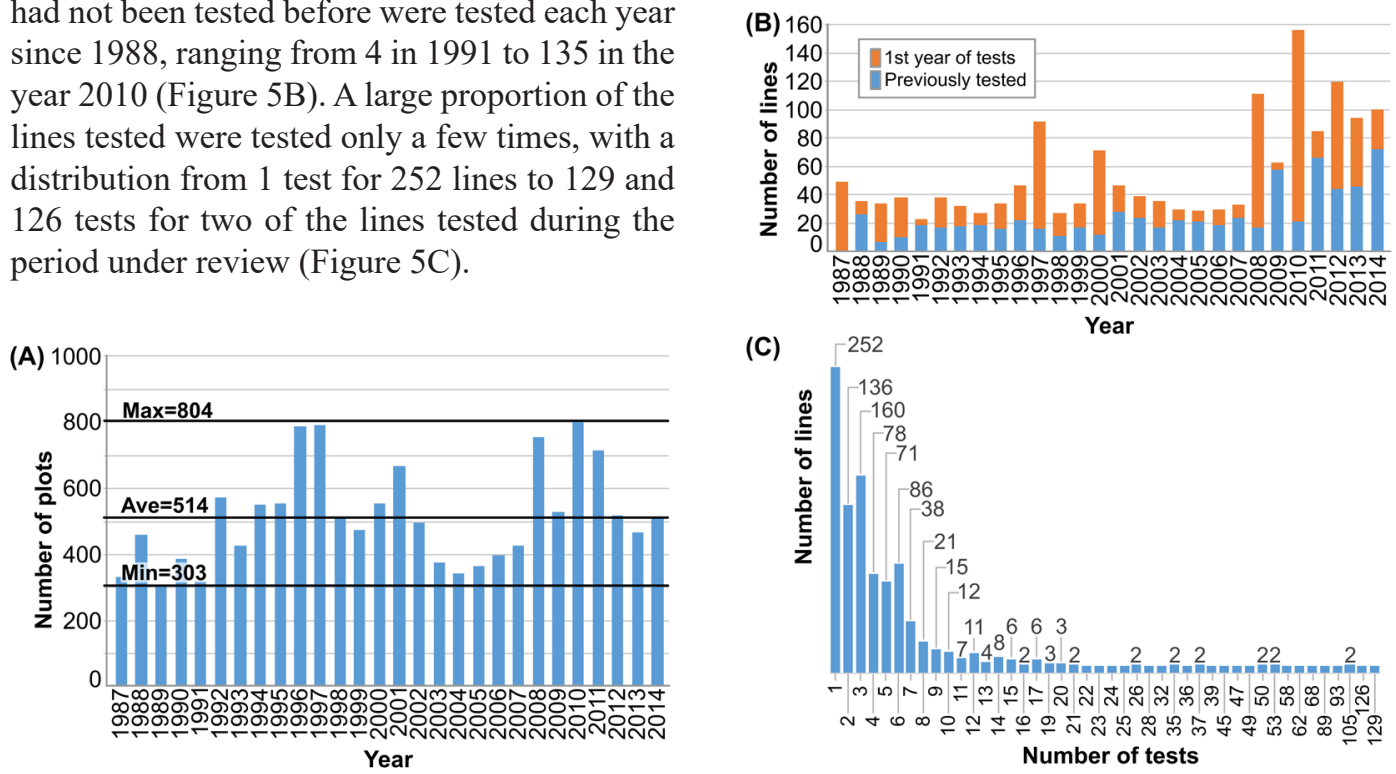

Figure 5. An overview of number of test plots and lines tested in 1987-2014. (A) The number of plots in Iceland, with an average number of 514 plots. (B) The number of cultivars/breeding lines tested each year in all trials, with cultivars/lines not tested previously shown in orange (top part of column) and cultivars/lines already tested shown in blue (bottom part of column). (C) The number of tests per line tested. Note that the number of tests (X-axis) is not continuous. 


\section{Length of growing season}

For the 14133 plots analysed here the day of sowing was recorded for 13419 plots (94.9\%), day of heading for 7426 plots $(52.5 \%)$, and day of harvest for 13403 plots (94.8\%) (Figure 6). The average day of sowing was 4 May (day 124 of the year), the earliest day of sowing was 17 April (day 108) at KRP in 1992 while the latest day of sowing was 26 May (day 146) at LGF in 1989 (Figure 6). The average day of heading was 17 July (day 198), with the earliest day of heading recorded 27 June at KRP in 2008 and the latest heading date recorded 18 August at LGF in 1989. However, the shortest interval from sowing to heading was 57 days in 1987 at GSN and the longest interval between sowing and heading was 110 days at KRP in 1992. The average day of harvest was 17 September (day 260), with the earliest recorded harvest date 25 August (day 237) at KRP in 1997 and the latest harvest date recorded 14 October (day 287) at POR in 2002. All three variables showed a trend towards earlier dates (Figure 6). During this period the time from sowing to harvest has shortened by 0.23 days on average annually, with the shortest time from sowing to harvest recorded 109 days in SIG in 1999 and the longest 171 days at POR in 2002 (Figure 7). The dry matter content has not changed since 1996, which was the earliest available data point (data not shown).

Comparison of the day of heading for all

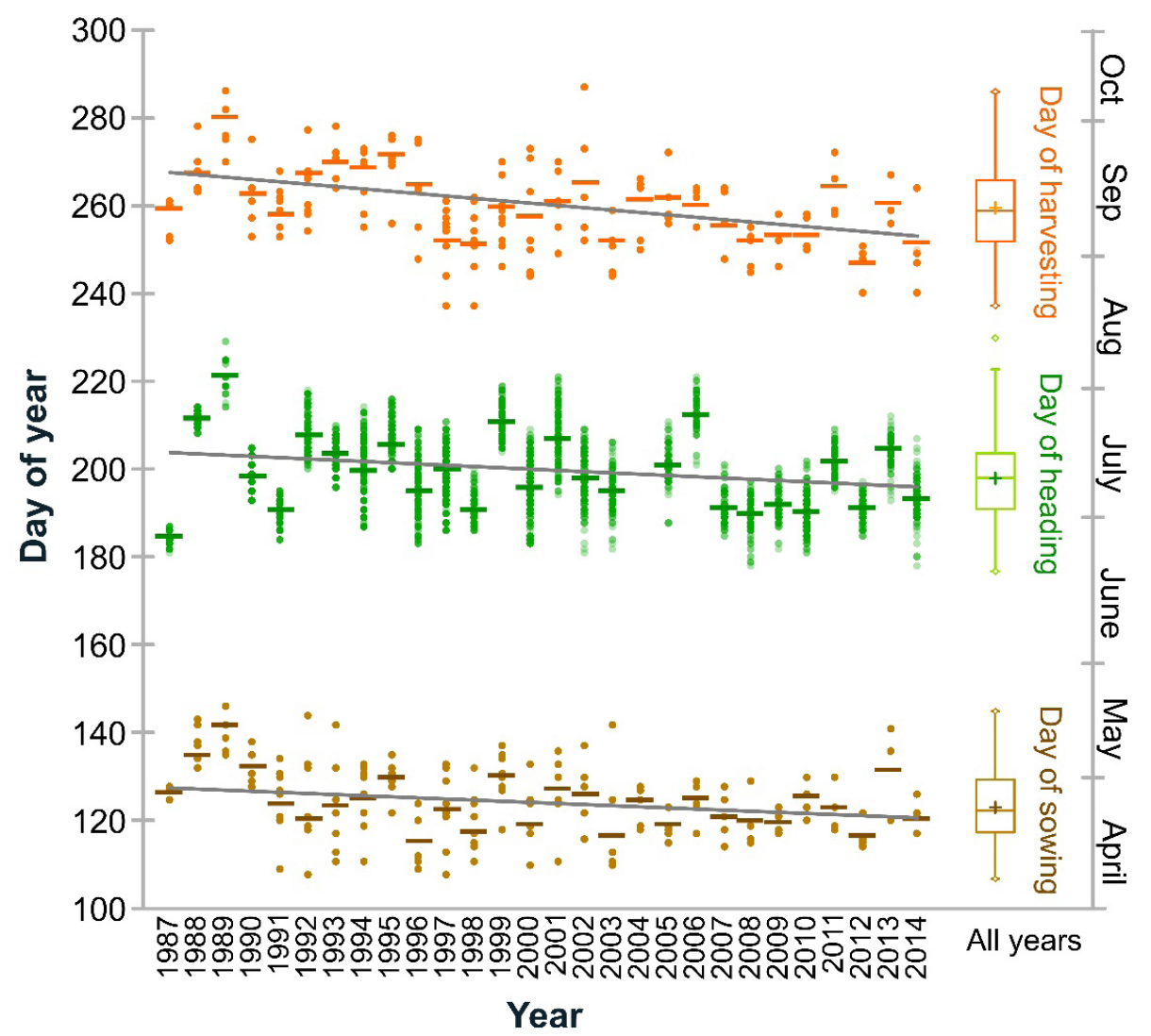

Figure 6. Results for three dates of importance for the barley growing season. The day of sowing (brown; $\mathrm{n}=13419$, average $=123.7, \min =108$ and $\max =146$ ), day of heading (green; $\mathrm{n}=7426$, average $=198.7, \min =178$ and $\max =272$ ), and day of harvesting (orange; $n=13403$, average $=259.9, \min =237$ and $\max =287$ ) for the years 1987-2014, with the average for all 28 years shown in boxplots on the right. Every data point is shown for all years with the average for each year shown as a bar. 


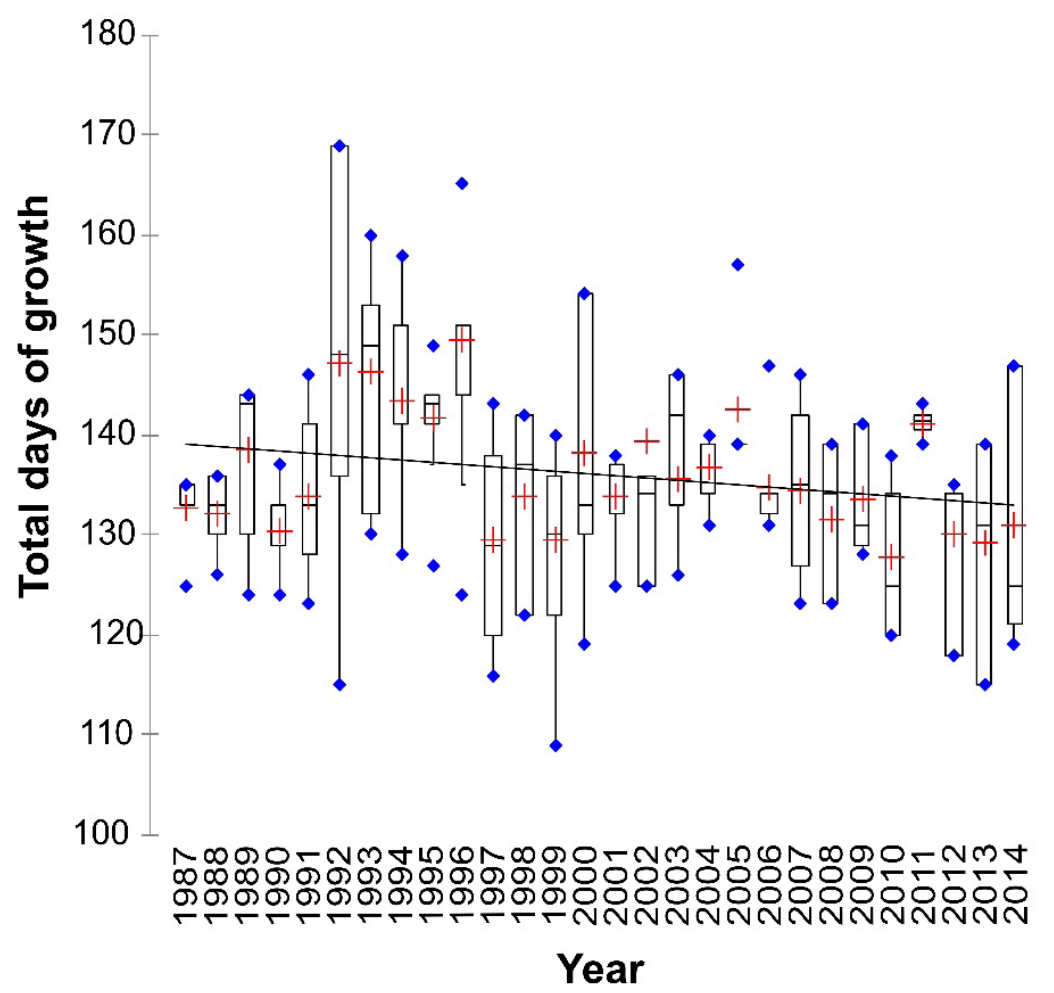

Figure 7. Box-plots showing number of days from sowing to harvest 1987-2014.

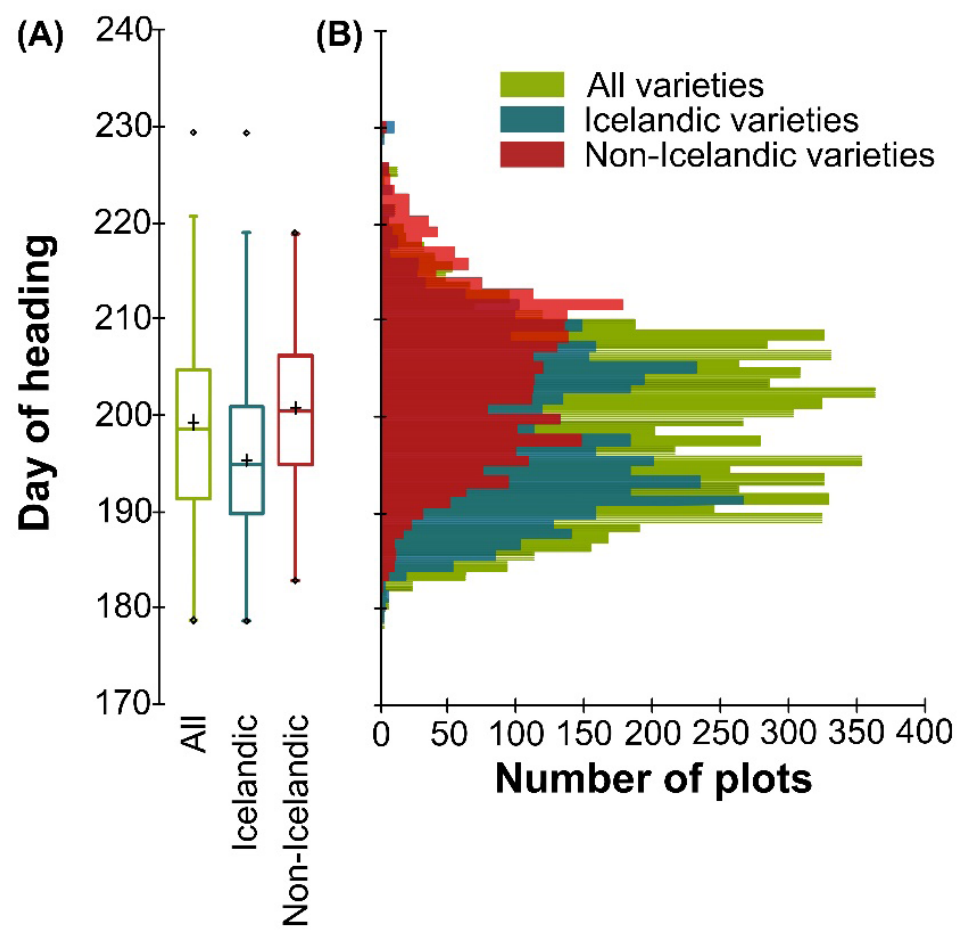

Figure 8. Day of heading for all tested barley cultivars and lines. (A) Boxplots showing the average value for day of heading for all cultivars tested (green), all Icelandic material (blue) as well as all foreign material (red). (B) A histogram showing the frequency distribution of values for day of heading. 

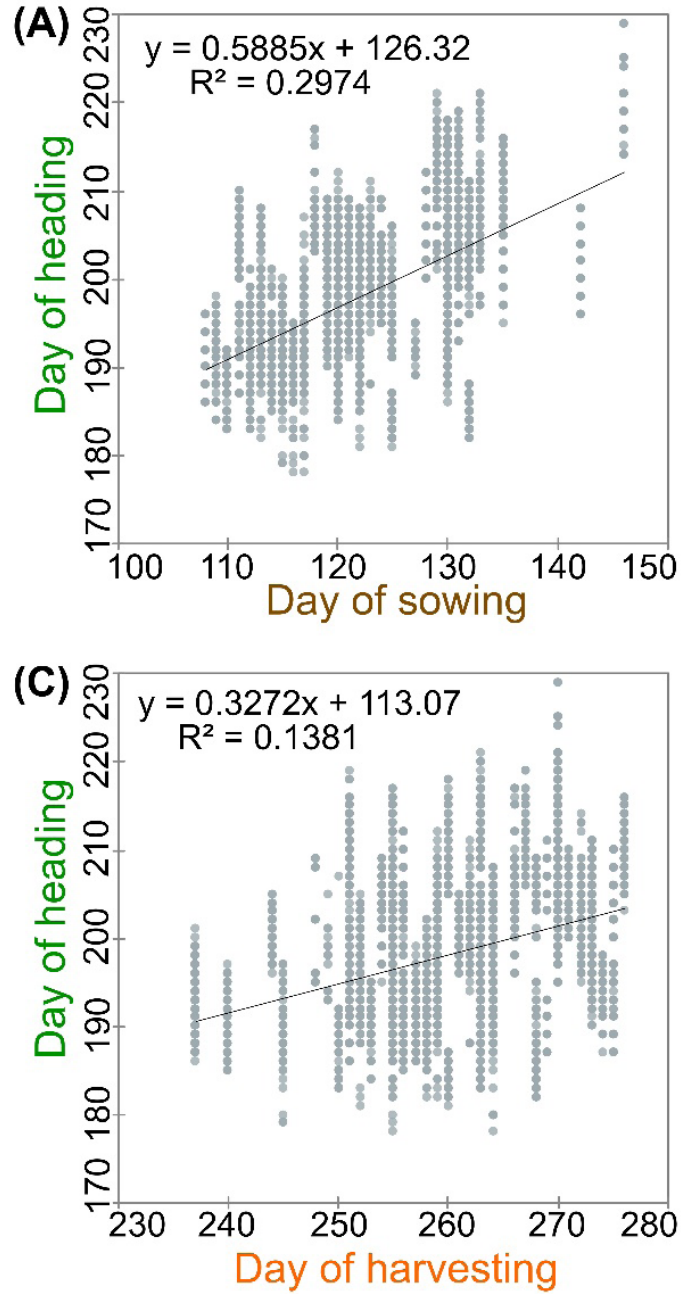

lines in all years showed a slight difference between the average day of heading for Icelandic and foreign lines and cultivars (Figure 8A). The variation was great within the dataset for both the Icelandic and foreign material (Figure 8B). Interestingly, the histogram of days of heading showed evidence of two peaks for the Icelandic material (Figure 8B). A significant positive correlation $(\mathrm{P}<0.0001)$ was seen between all dates with the highest correlation between day of sowing and day of heading $\left(r^{2}=0.297\right)$, a somewhat lower correlation between day of heading and day of harvesting $\left(r^{2}=0.138\right)$, and the lowest correlation between day of sowing and day of harvesting $\left(r^{2}=0.118\right)$ (Figure 9).

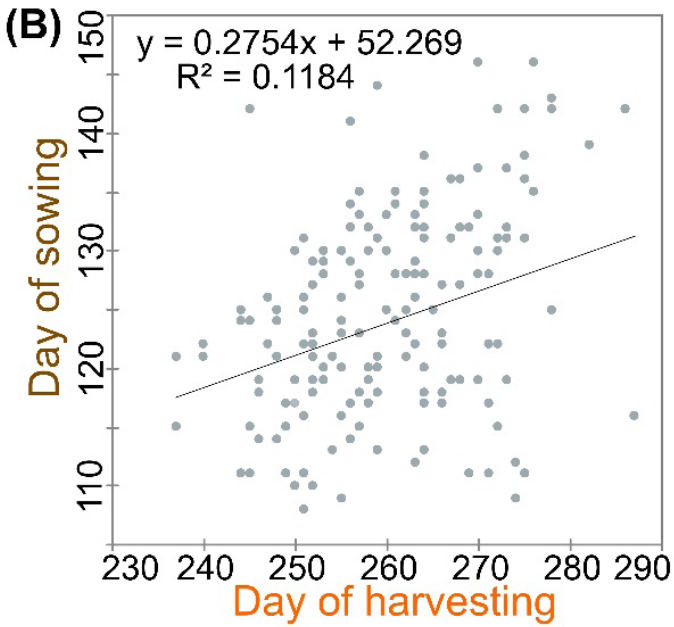

Figure 9. Correlation between different dates of importance for the growing season. (A) A scatterplot comparing day of sowing and day of heading ( $\mathrm{n}=6039$ ). (B) A scatterplot comparing day of sowing and day of harvesting $(n=12465)$. (C) A scatterplot comparing day of heading and day of harvesting ( $n=6039$ ). Low levels of correlation between the three variables are seen in all cases, with the lowest correlation seen between day of sowing and day of harvesting.

\section{Yield, TKW, and $\mathrm{w} / \mathrm{v}$}

Yield was measured for 14072 plots, TKW for 14364 plots, and w/v for 13949 plots. Averages of all lines for each location (Figure 10) and each year (Figure 11) showed great variation within and between both years and locations. The highest median of yield was $88.0 \mathrm{hkg}$ DM $\mathrm{ha}^{-1}$ in GRG, the highest median for TKW was $40.0 \mathrm{~g}$ at KRP, as well as the highest median for seed w/v $66.7 \mathrm{~g} \mathrm{dL}^{-1}$. The lowest median for yield was $7.2 \mathrm{hkg} \mathrm{DM} \mathrm{ha}^{-1}$ in SLD, the lowest median for TKW was $17 \mathrm{~g}$ at HJR, as well as the lowest median for w/v $38 \mathrm{~g} \mathrm{dL}^{-1}$ (Figures 10AC). 


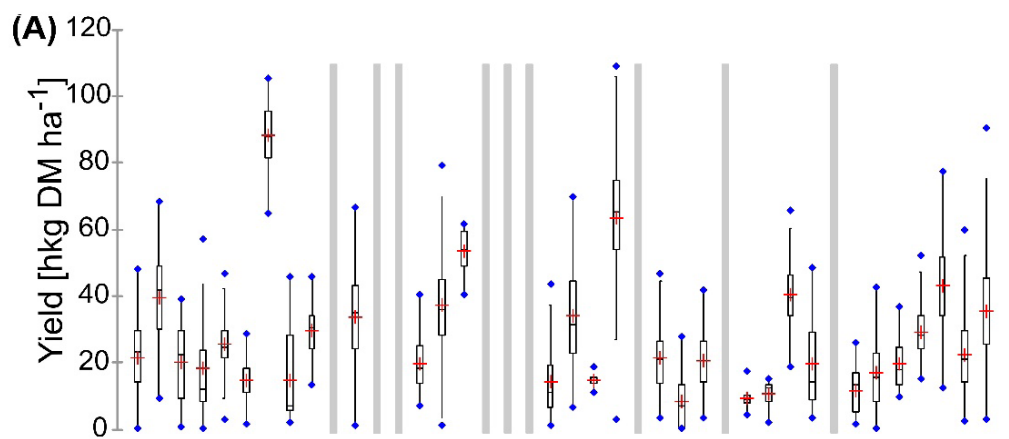

(B)

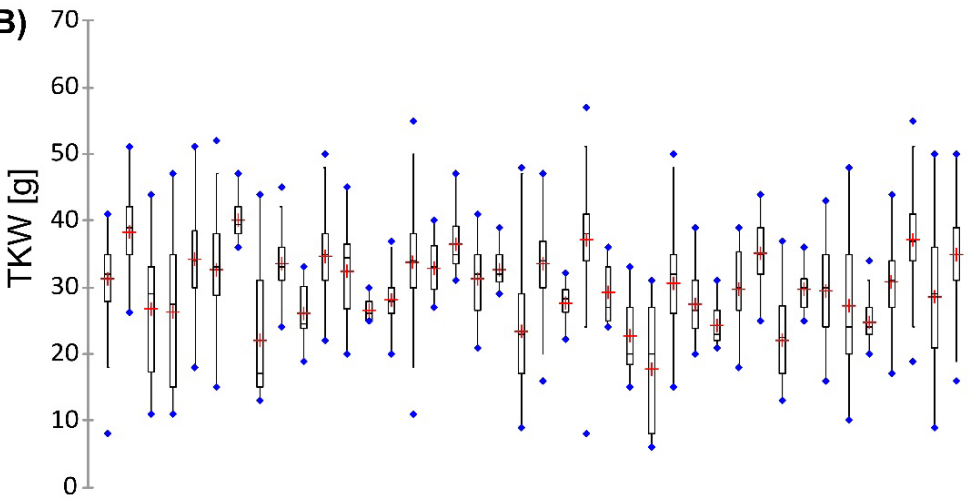

(C) 90

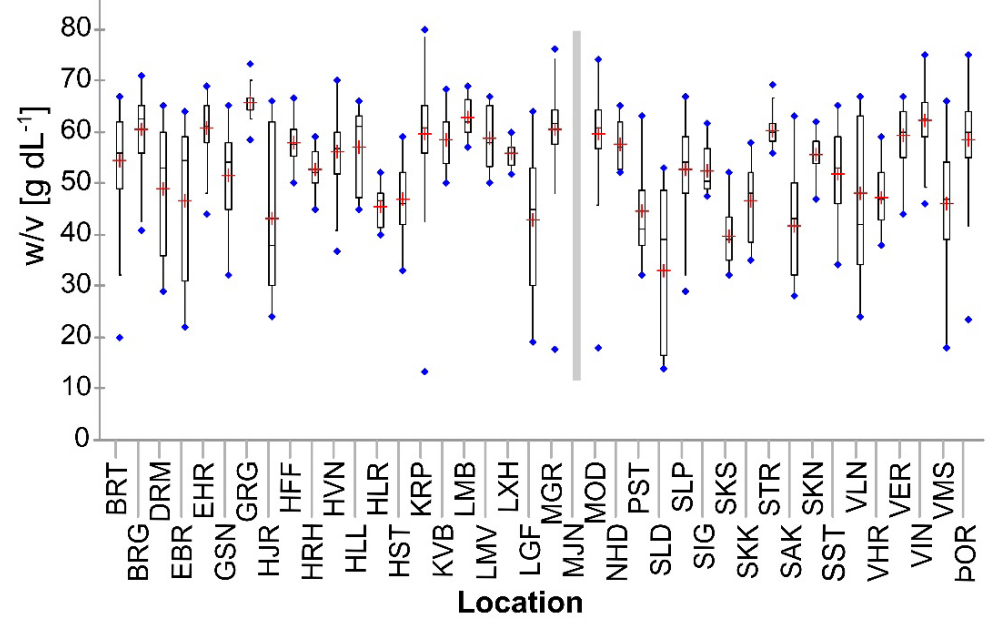

Figure 10. Average values for yield, thousand-kernel weight and weight by volume in the period 19872014 at 40 test locations in Iceland. (A) Yield for all years and genotypes in hecto kilograms dry matter per hectar (hkg DM ha $^{-1}$ ). (B) Thousand-kernel weight for all years and genotypes in grams (g). (C) Weight by volume for all years and genotypes as grams per $\mathrm{dL}\left(\mathrm{g} \mathrm{dL}^{-1}\right)$.
Averages for years showed that the values for the three measurements have all increased in field trials, although not in the last few seasons. For yield the increase was $12.93 \mathrm{~kg}$ $\mathrm{DM} \mathrm{ha}^{-1}$ per year $\left(r^{2}=0.637\right), 0.34 \mathrm{~g}$ per year $\left(r^{2}=0.270\right)$ for TKW, and $0.59 \mathrm{~g} \mathrm{dL}^{-1} \mathrm{ha}^{-1}$ per year for $\mathrm{w} / \mathrm{v}\left(r^{2}=0.382\right)$. The highest and lowest annual medians for all locations of all three measurements was $56 \mathrm{hkg} \mathrm{DM} \mathrm{ha}^{-1}$ in 2009 and $7.7 \mathrm{hkg} \mathrm{DM} \mathrm{ha}^{-1}$ in the year 1989 for yield, $41 \mathrm{~g}$ and $18 \mathrm{~g}$ for the TKW in the years 2008 and 1989, respectively, and $65 \mathrm{~g} \mathrm{dL}^{-1}$ and 31 $\mathrm{g} \mathrm{dL}^{-1}$ for the $\mathrm{w} / \mathrm{v}$ in the years 2012 and 1989 , respectively (Figure 11).

A comparison of all three measurements between Icelandic and foreign lines for all 


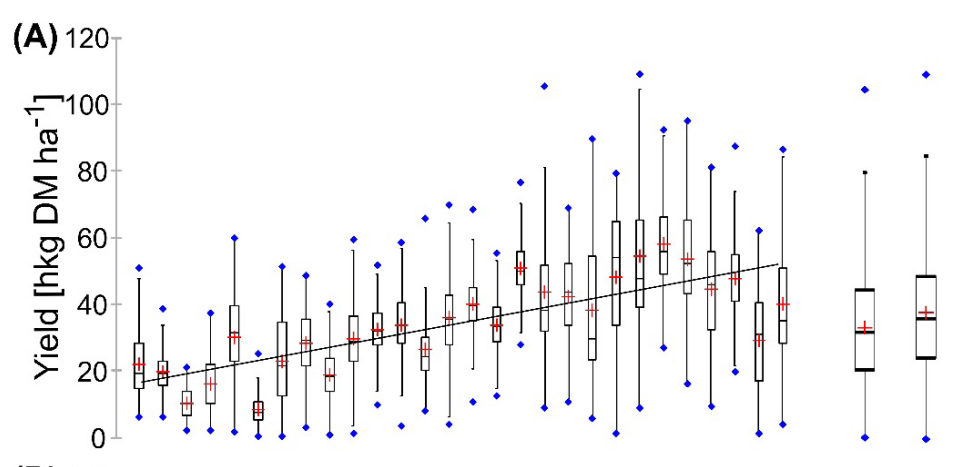

(B) $70^{-}$

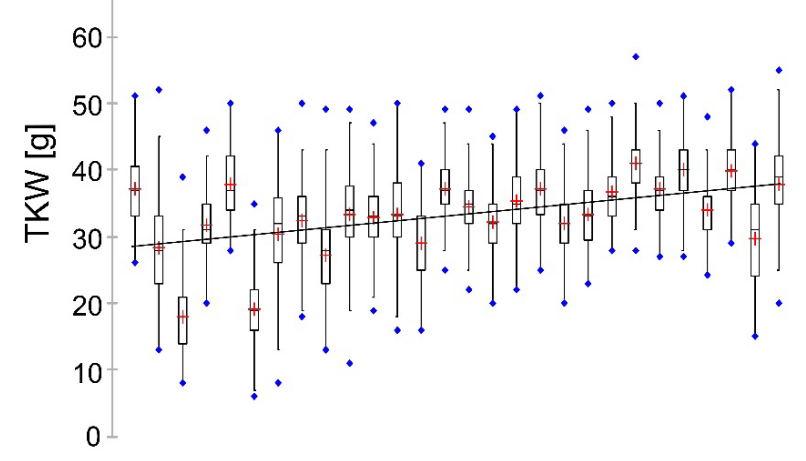

(C) 90

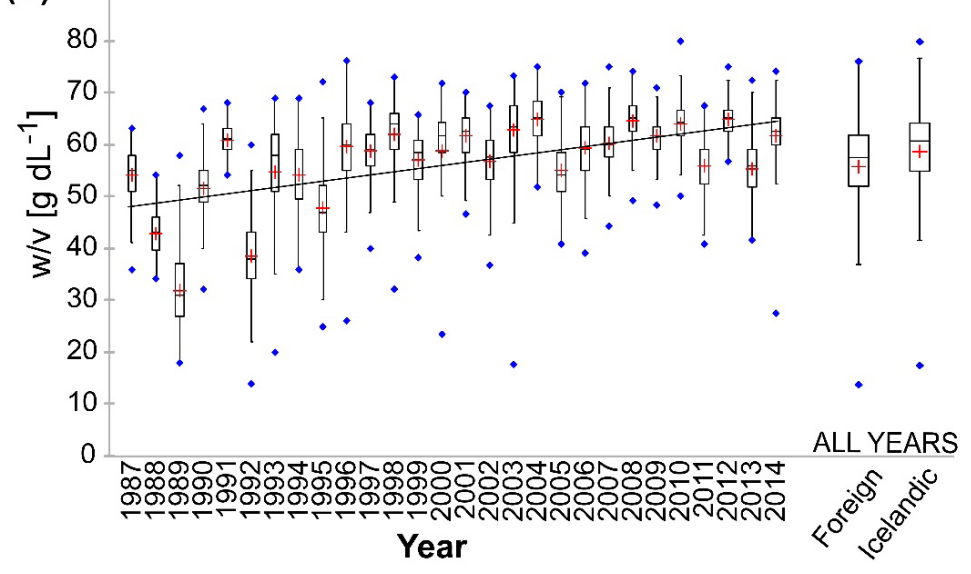

Figure 11. Average values for yield, thousand-kernel weight, and weight by volume at 40 test locations for the period 1987-2014. (A) Yield for all locations and genotypes in hecto kilograms dry matter per hectare (hkg DM ha-1). (B) Thousand-kernel weight for all locations and genotypes in grams (g). (C) Weight by volume for all locations and genotypes as grams per $\mathrm{dL}\left(\mathrm{g} \mathrm{dL}^{-1}\right)$. locations and years showed slightly higher averages for the Icelandic lines. The medians were 32.1 and $35.8 \mathrm{hkg} \mathrm{DM} \mathrm{ha}^{-1}$ for yield, 32 and $36 \mathrm{~g}$ for TKW, and 57.5 and $60.8 \mathrm{~g} \mathrm{dL}^{-1}$ for $\mathrm{w} / \mathrm{v}$ for the foreign and the Icelandic genotypes, respectively (Figure 11). Despite the great variation within locations and years no clear differences were seen between Icelandic and foreign cultivars, although the range of values was always greater, and the average values slightly higher, for the Icelandic barley lines (Figures 10 and 11).

Scatterplots of yield, TKW and w/v all exhibited a significant positive correlation $(\mathrm{P}<0.0001)$, with $\mathrm{w} / \mathrm{v}$ and TKW showed the strongest correlation of the three $\left(r^{2}=0.628\right)$, yield and $\mathrm{w} / \mathrm{v}\left(r^{2}=0.305\right)$ and finally yield and TKW $\left(r^{2}=0.285\right)$ (Figure 12). 

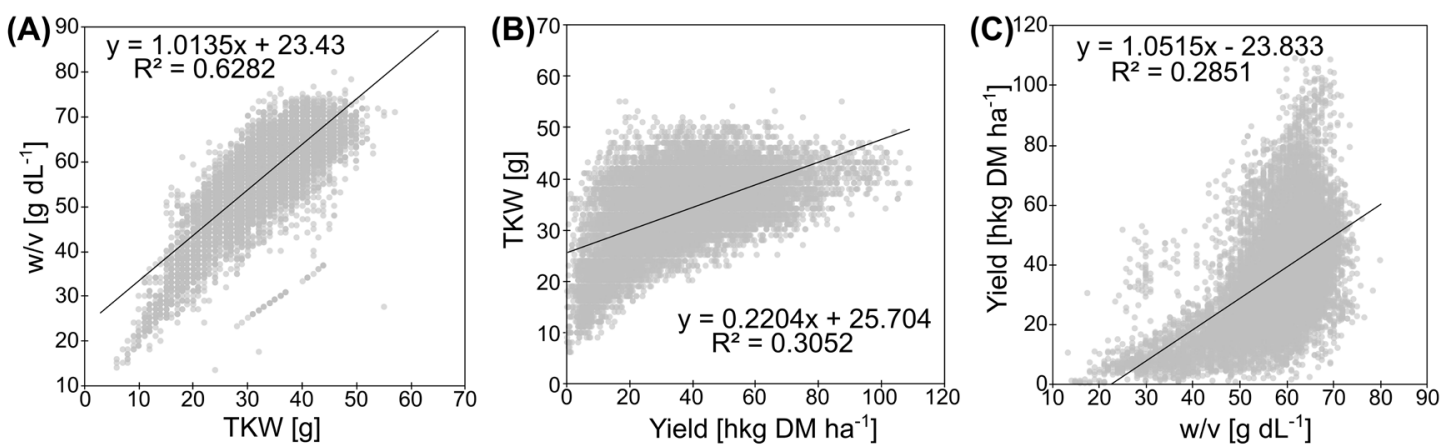

Figure 12. Scatterplots showing correlation between yield, thousand-kernel weight, and weight by volume. (A) Weight by volume and thousand-kernel weight. (B) Estimated yield and thousand-kernel weight. (C) Estimated yield and weight by volume.

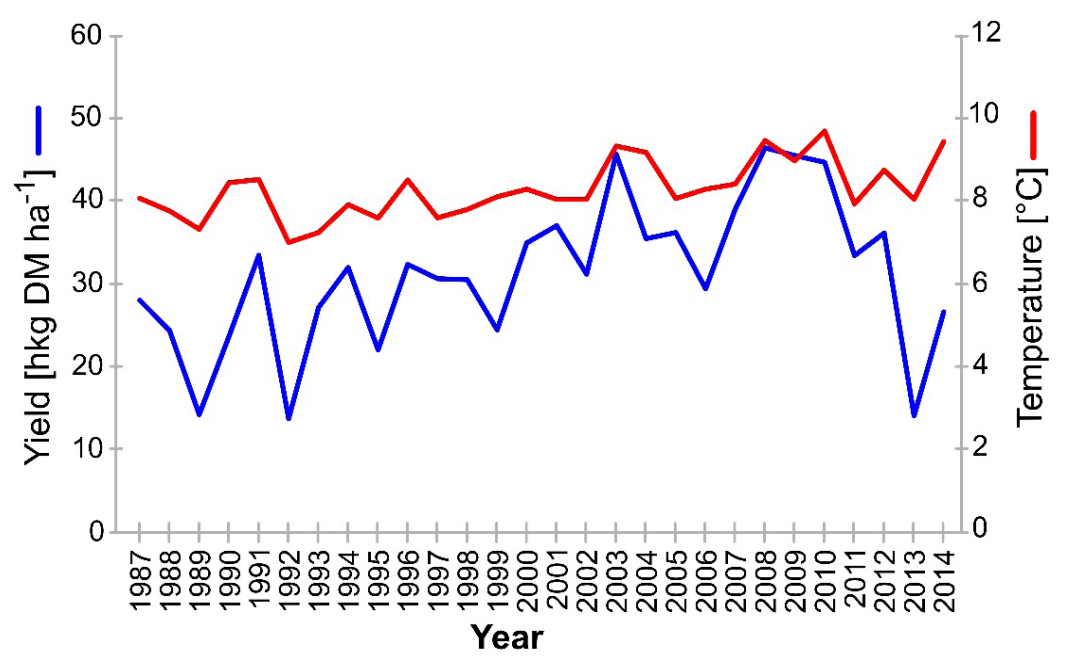

Figure 13. Lsmeans for yield and the average annual temperature. Yield (in hkg DM ha ${ }^{-1}$ ) is shown on the left Y-axis (with a blue line) and the mean temperature (in ${ }^{\circ} \mathrm{C}$ ) for the average growing season in Stykkishólmur is shown on the right Y-axis (with a red line).

The mean temperature during the average growing season at Stykkishólmur varied from $7.6^{\circ} \mathrm{C}$ in 1992 and up to $10.5^{\circ} \mathrm{C}$ in 2010 . The lsmeans for yield and the mean growing season temperature (Figure 13) showed a positive correlation $\left(r^{2}=0.49 ; \mathrm{y}=9,0976 \mathrm{x}-47,92 ; \mathrm{P}=\right.$ $<0.0001)$.

\section{DISCUSSION}

Shorter growing season

A striking result was that the time from sowing to harvest shortened by 6.3 days in the period under review (Figure 7), and although both day of sowing and day of heading were getting earlier, the major shift was towards earlier harvest dates (Figure 6). This trend was not at the expense of yield, TKW, or w/v with all values on the rise during the same period (Figure 11). The trend seen here contrasted with results of barley breeding in Finland in the years 1973-2003 which resulted in a longer growth period of 3.4 days (Öfversten et al. 2004) and in 
the north of Scotland where the growing season increased by 31\% from 1960-2003 (Reykdal et al. 2014). Correlating days of sowing, heading and harvesting shows that the effect of 'day of sowing' has only a modest effect on the dates of heading and harvest (Figure 9), which strongly suggests that other environmental factors were at play. Temperature during the growing season has, for example, been reported as the deciding factor on yield in Norway (Lillemo et al. 2010) although it has been pointed out that heat sum requirements are lower for plant species in the Arctic due to longer photoperiods (Bergpórsson 1987). There was a strong positive correlation between temperature during the growing season and yield (Figure 13), where the yield generally followed the annual fluctuations in mean temperature during the growing season. However, average temperatures did not explain all the low yields, e.g. in 2013 and 2014. Other weather conditions might be at play and are worth examining further. The extremely low yield observed in 2013 (Figure 13) could also be explained by the late sowing date that year (Figure 6).

\section{Extreme variability}

Although the data presented here showed some extreme values that might be considered obvious outliers and should as such be removed, it is not impossible that these represent biological variability in the material tested. Should the outliers truly represent biological variability, removing them from the dataset would lead to an underestimation of the variability of the data (Altman \& Krzywinski 2016); the decision was therefore not to remove possible outliers from the dataset but rather to attempt to describe the possible extreme variability. Among the most extreme values seen in the dataset were the high yield values for the test location GRG. Since the trial at GRG was only conducted for a single year in 2004, a year that was climate-wise generally good in the northern part of Iceland, medians are expected to turn out high when compared to other locations that have a median based on a wider range in time. But these very high yield values might also be explained by a 'border effect' (Gomez 1972), resulting from the fact that the experimental plots were sown as wide as they were cut, with paths between plots. In warm summers with favourable precipitation, the paths might have been used by the plants for photosynthesis at the borders of plots which would increase yield without affecting the total area. This effect might explain the very high yields at GRG as well as at MOD, as seen in Figure 10A. Although this effect would not necessarily affect the comparison between genotypes within locations it might explain the results seen when correlating different yield components, with yield rising greatly in comparison to TKW and w/v, leading to lower correlations between yield on one hand and $\mathrm{w} / \mathrm{v}$ and TKW on the other (Figure 12). This problem could be, at least partly, avoided by sowing wider plots and harvesting only from within them, leaving the border uncut. In this study we did not address whether the rising yield seen here from year to year could be explained by new and improved cultivars, enhanced crop management and/or improved weather conditions. Which factor contributes most to increasing yields, therefore remains unclear. However, breeding strategies in Norway in 1960-1992 have been shown to explain about $40 \%$ of the observed yield improvement (Strand, 1994). Cultivar trials conducted in the years 1987-1989 in the Nordic countries resulted in yields below 25 hkg DM ha-1 at GSN (Nurminiemi et al. 1996), leading to the conclusion that barley cultivation was at its margin in the southern part of Iceland. Results represented here support this as the average yield measured at GSN was below 20 hkg DM ha-1. However, it interesting to observe other high yielding locations in the north and average yields for the whole timespan at e.g. KRP around $40 \mathrm{hkg} \mathrm{DM} \mathrm{ha}^{-1}$ (Figure 10A).

The discontinuity of test locations and reference lines seen in this study is of concern in long term trials. However, it might be that the four remaining locations used for testing since 2008 are the result of testing in many locations - that these four locations represent all environments in Iceland. This could be investigated by identifying mega-environments 
in Iceland using GGE biplots (Yan et al. 2000). Another aspect of the experimental set-up worth considering is that it does not allow us the opportunity of assessing the maturity of individual genotypes in the trials, since each trial was harvested all at the same time. This means that some lines or genotypes might mature long before harvest while others were far from ready. Therefore, genotypes that mature earlier, which means they were more reliable in years of severe weather conditions, could start to lose grains resulting in a lower estimated yield. If the trials were harvested too early, genotypes that mature later will not have reached their full potential and will exhibit lower values for yield, TKW, and w/v. It is important to note that in some years with unfavourable autumn weather, trials were not harvested at all. In such years 'high risk' genotypes, that is genotypes that mature late but give higher yields in good years, were sometimes not harvested and so the averages of those genotypes do not suffer for the years of crop failure. The results of the breeding trials have therefore benefited 'high risk' genotypes and put more stable genotypes at a disadvantage. Also, in years of favourable weather experiments might be harvested early when some genotypes were ready and some have yet to reach their full potential.

\section{CONCLUSIONS}

Here we present an overview and the first results from an ongoing barley breeding and cultivar testing program in Iceland. The results showed that the number of test locations decreased during the period 1987-2014, while the number of cultivars and lines tested increased. The results also showed that no test location has been used throughout the period under review, complicating comparison of results between years. The increase in yield seen in the trials presented can most likely be explained by a combination of factors, including continuous testing and breeding of new and improved cultivars, enhanced crop management, and more favourable weather conditions. The reason for the yield increase should be addressed in future studies. For ongoing tests, it would be necessary to keep in mind the importance of both reference locations and reference cultivars in order to facilitate comparison over time. Also, it is important to establish whether Iceland can be subdivided into distinct cultivation areas, which could, for example, affect the number and location of test sites used for further testing.

\section{ACKNOWLEDGEMENTS}

The authors would like to thank Professor Áslaug Helgadóttir for constructive comments on the work presented here at earlier stages. The work was funded in part by a grant from the Agricultural Productivity Fund.

\section{REFERENCES}

Allaby RG 2015. Barley domestication: the end of a central dogma? Genome Biology 16, 176. doi: http://doi.org/10.1186/s13059-015-0743-9

Altman N \& Krzywinski M 2016. Points of Significance: Analyzing outliers: Influential or nuisance? Nature Methods 13, 281-282.

doi: http://doi.org/10.1038/nmeth.3812

Bergthórsson P, Björnsson H, Dýrmundsson $O$, Gudmundsson B, Helgadóttir A \& Jónmundsson JV 1987. The effect of climatic variations on agriculture in Iceland. In: Parry ML, Carter TR \& Konijn NT (Eds). The Impact of Climatic Variations on Agriculture, Vol I: Assessments in Cool Temperature and Cold Regions. Kluwer Academic Publishers Group, Dordrecht. pp. 383509.

Community Plant Variety Office (CPVO) 2016. http://www.cpvo.europa.eu/main/en/home. Accessed 11.04.2016, at http://www.cpvo.europa. eu/main/en/home

Food and Agriculture Organization of the United Nations (FAO) 2017. Accessed 15.01.2017 at http://faostat.fao.org

Fjölrit RALA, Nrs. 132, 136, 145, 152, 154, 165, $175,181,185,189,193,198,205,208,210,213$, 215 [RALA Report Field Experiments, Field Research] 1988-2004. Accessed 01.03.2016 at http://landbunadur.is [In Icelandic].

Gomez 1972. Border effects in rice experimental plots. II. varietal competition. Experimental Agriculture 8, 295-298.

doi: https://doi.org/10.1017/S001447970000541X 
Gustafsson Å, Hagberg A, Persson G \& Wiklund K 1971. Induced mutations and barley improvement. Theoretical and Applied Genetics 41, 239-248. doi: http://doi.org/10.1007/BF00277792

Hermannsson J 1993. Kornrækt á Íslandi [Barley cultivation in Iceland]. In Rádunautafundur 1993. Búnaðarfélag Íslands og Rannsóknastofnun landbúnaðarins, Reykjavík. pp. 178-187 [In Icelandic].

Karlsson G 2009. Lifsbjörg íslendinga frá 10. öld til 16. aldar (1st ed.) [Subsistence of Icelanders from the $10^{\text {th }}$ century to the $16^{\text {th }}$ century]. Reykjavik, Iceland: University of Iceland Press. 165 p. [In Icelandic].

Lillemo M, Reitan L \& Bjørnstad A 2010. Increasing impact of plant breeding on barley yields in central Norway from 1946 to 2008. Plant Breeding 129, 484-490. doi: http://doi.org/10.1111/j.1439-0523.2009.01710.x

Lundqvist U 2008. Eighty years of Scandinavian barley mutation research and breeding. Accessed 01.03.2016 at http://inis.iaea.org/Search/search. aspx?orig_q=RN:39113986

Miller GH, Geirsdóttir Á, Zhong Y, Larsen DJ, Otto-Bliesner BL, Holland MM, Bailey DA, Refsnider KA, Lehman AJ, Southon JR, Anderson C, Björnsson $\mathbf{H} \&$ Thordarson $T$ 2012. Abrupt onset of the Little Ice Age triggered by volcanism and sustained by sea-ice/ocean feedbacks. Geophysical Research Letters 39, L02708.

doi: http://doi.org/10.1029/2011GL050168

Nurminiemi M, Bjørnstad Å, \& Rognli OA 1996. Yield stability and adaptation of Nordic barleys. Euphytica 92, 191-202. doi: http://doi.org/10.1007/BF00022845

Öfversten J, Jauhiainen L \& Kangas A 2004. Contribution of new varieties to cereal yields in Finland between 1973 and 2003. The Journal of Agricultural Science 142, 281-287.

doi: http://doi.org/10.1017/S0021859604004319

Ortiz R, Nurminiemi M, Madsen S, Rognli OA \& Bjørnstad § 2002. Genetic gains in Nordic spring barley breeding over sixty years. Euphytica 126, 283-289.

doi: http://doi.org/10.1023/A:1016302626527

Peltonen-Sainio P \& Karjalainen R 1991. Genetic yield improvement of cereal varieties in northern agriculture since 1920. Acta Agriculturae Scandinavica 41, 267-273.

doi: http://doi.org/10.1080/00015129109439909

Poets AM, Fang Z, Clegg MT \& Morrell PL 2015. Barley landraces are characterized by geographically heterogeneous genomic origins. Genome Biology 16, 173.

doi: http://doi.org/10.1186/s13059-015-0712-3

Reykdal Ó, Kristjánsdóttir PA, Hermannsson J, Martin P, Dalmannsdóttir S, Djurhuus R, Kavanagh V \& Frederiksen A 2014. Status of Cereal Cultivation in the North Atlantic Region (No. 23-14). MATIS.

Rit LbhÍ, Nrs. 6, 11, 12, 18, 22, 33, 41, 44, 47, 60 [Annual field trial reports] 2005-2015. Accessed 01.03.2015 at http://www.lbhi.is/?q=is/rit_lbhi_0 [In Icelandic].

Riggst TJ, Hanson PR, Start ND, Miles DM, Morgan CL \& Ford MA 1981. Comparison of spring barley varieties grown in England and Wales between 1880 and 1980. The Journal of Agricultural Science 97, 599-610.

doi: http://doi.org/10.1017/S0021859600036935

Strand E 1994. Avlingsframgang og årsaker til avlingsframgang i norsk korndyrking 1960-92. [Yield progress and sources of yield progress in Norwegian small grain production 1960-92] Norsk Landbrugsforsking 8, 111-126. [In Norwegian with an English Abstract].

Yan WK, Hunt LA, Sheng QL \& Szlavnics Z 2000. Cultivar evaluation and mega-environment investigation based on the GGE biplot. Crop Science 40, 597-605.

Zakhrabekova S, Gough SP, Braumann I, Müller AH, Lundqvist J, Ahmann K, Dockter C, Matyszszak I, Kurowska M, Druka A, Waugh R, Graner A, Stein N, Steueragel B, Lundqvist U \& Hansson M 2012. Induced mutations in circadian clock regulator Mat-a facilitated shortseason adaptation and range extension in cultivated barley. Proceedings of the National Academy of Sciences 109, 4326-4331.

doi: http://doi.org/10.1073/pnas.1113009109

Manuscript received 9 December 2016 Accepted 20 February 2017 